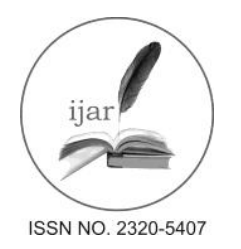

\author{
Journal homepage: http://www.journalijar.com

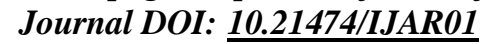

INTERNATIONAL JOURNAL

OF ADVANCED RESEARCH

RESEARCH ARTICLE

\title{
DISSECTING THE LAYERS OF PERFORMATIVITY, FEMININITY, MODERNITY AND SEXUALITY IN THE SHADOW LINES BY AMITAV GHOSH
}

\author{
Bharti Silswal. \\ Research Scholar, Dept. of English, Birla Campus, H.N.B. Garhwal University (A Central University), Srinagar \\ (Garhwal), Uttarakhand.
}

\section{Manuscript Info}

Manuscript History:

Received: 19 May 2016

Final Accepted: 22 June 2016

Published Online: July 2016

Key words:

*Corresponding Author

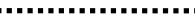

Bharti Silswal

\section{Abstract}

The present research paper traces the concept of freedom, modernity, performativity, femininity and sexuality in the novel The Shadow Lines by Amitav Ghosh. For the analysis, I have applied theories of Freud, Lacan, Simone de Beauvoir, D. H. Lawrence, Judith Butler and Michel Foucault.

For its sensitivity of perception, the living Indian quality of its language and its expert recreation of atmosphere, this book is considered an outstanding contribution to Indian English literature. (The Sahitya Akademi citation, qtd. in Banerjee 44)

Published in 1988, The Shadow Lines was the second novel penned by Amitav Ghosh, which bags him Sahitya Akademi Award in 1989. It owes its title to Joseph Conrad's novel The Shadow Lines (1917). "In respect of Conrad's protagonist 'The Shadow Lines' means an invisible line that divides youth from maturity while in Ghosh's work it refers to geographical boundaries arbitrarily drawn by man to fragment humanity" (43). The novel is divided into two parts: 'Going Away' and 'Coming Home,' which tells the story of three generations of the Narrator's family and the riots of Dhaka and Calcutta in 1964.

Ghosh is best known for his subversive encounter with constant construal. He is well known for his unceasing confrontation with the preset history. He gave platform to the silent unheard voices of the past. In general, sexuality is also a victim of cast-iron mould. Most of the problems occurred due to our unwillingness to accept the peripheral episteme as truth. Ghosh talks about his "struggle with silence" (Ghosh, SL 240), which is beyond words and symbolisation, like 'das ding' or 'object petit a'. The same is the core concern of feminism, which prominently includes the stereotyping of sexual roles and beliefs. We must not accept the conventional notions of sexuality without giving it a rational thought.

Freedom is the undercurrent theme of $S L$. In this novel, every character has his own odyssey towards freedom. Tha'mma thinks of freedom in terms of nationalism and political freedom, Ila wants freedom from the fetters of suppressive patriarchal norms, Tridib finds his freedom in his imaginative world far-off from abstruse realities of life, Narrator seeks his freedom in his indulgence in memories whereas Robi wants the reverse.

Basically, it is the cause that gives meaning to the words. Most of us use the word 'freedom' without giving it a serious thought. Tha'mma has her own notion of freedom, Ila has her own idea of freedom, so do Robi, May, Tridib, and Narrator. It is this difference of opinions, this clash of mindsets that hinder the actual freedom of others. Tha'mma's perception of freedom curbs Ila's domain of freedom; Tridib's notion of freedom annoys Tha'mma's notion of freedom; Robi's notion of freedom is just getting rid of memories - "I would have given anything to be 
free of that memories" (271); contradicting Narrator's notion of freedom, for whom memories are the best way to free one's self_-“I was happy to be bound" (98).

This tussle of perceptions and clash for their respective domains are the principal cause of trouble for sexuality. Woman's notion of freedom directly opposes man's notion of freedom. They were genderised as such that they take themselves contrary to each other and hardly show any interest for co-existence in most of the cases. Both men and women are one species - human species, with different productive roles, as simple as that. Yet this simple truth is deliberately concealed and relegated.

Gendering is one of the most important tools that curb our freedom. Procuring freedom is quite illusive, for our choices are always limited from the beginning as Butler puts it. It is not easy to transgress our gender role in the society. Tha'mma and Ila tried but eventually failed. Tha'mma chooses the role that was originally assigned to male - to fight, to protect - but eventually realized her limitation as a woman. Tha'mma realized it very clearly and despite her zeal to serve her country in freedom struggle, she remained aloof:

Ever since she heard those stories, she had wanted to do something for the terrorists [here it means nationalists], work for them in a small way, steal a little bit of their glory for herself. She would have been content to run errands for them, to cook their food, wash their clothes, anything. But, of course, they worked secretly; she did not know how to get in touch with them, and even if she had it would have been twice as hard for her to get in, because she was a girl, a woman. (43)

What is so interesting here is that, cooking, washing are considered insignificant work. This work-divisionimportant work and unimportant work - is one of the chief tools of women's suppression. To woman, all so-called unimportant works were assigned_cooking, washing, sweeping and child bearing and rearing. Interestingly this work-division also continued in sexual domain, e.g. throughout history phallus was given more importance than vagina, male is seen as an active agent while female as a passive agent. Procreation is a joint venture; here both man and woman matter. Phallus alone cannot produce children, it needs womb. If man needs woman to enjoy sensuality, similarly woman also needs man to enjoy her sexuality in heterosexual format. Both are active agents in their own respective domain. Both are equal, still projected as unequal. This is the working of patriarchy, a discursive management, which needs to be deconstructed.

It is the case with Ila. She represents the concept of 'modern girl.' The 'modern girl' is a symbol of Westernization, extravagance and selfish choices. "Modern girls (モダンガール, modan gāru, also shortened to moga) were Japanese women who followed Westernized fashions and lifestyles in the 1920s. These moga were Japan's equivalent of America's flappers, Germany's neue Frauen, France's garçonnes, or China's modeng xiaojie (摩登小姐)” (www.google.co.in, <https://en.wikipedia.org/wiki/Modern_girl>).

Modern girls were depicted as living in the cities, being financially and emotionally independent, choosing their own suitors, and apathetic towards politics. Modern girls were not political and did not protest. Each woman sought change via herself. Consumerism drove everything they did. They would work service industry styled jobs and live on their own, not dependent on family. They smoked, watched movies, and hung out at the cafes. They were sexually liberated, choosing their own suitors. Many of them participated in casual sex.

Ila thought she could be free by escaping India and its rigid culture, by being 'modern girl.' But does she really attain her freedom? Of course not. Patriarchy rules emphatically across culture, and border. Nick Price arrogantly warns Ila that she should not take him for granted just because he lives in a flat brought by her parents, and because she got a job while he is still unemployed. What makes him so superior? Of course his male-status; man, simply by being a man rules woman. He does not require any other qualification to be her superior. He is 'transcendent' by means of his biology - the possessor of 'anagkaion' (phallus). "To be a man is to be possessed exclusively by the phallic function" (Hill, 132). In spite of her rebellious attitude, Ila finally yielded to the set definition womanhood by proclaiming - 'I never did any of those things: I'm about as chaste, in my own way, as any woman you'll ever meet" (Ghosh, SL 207). Thus, she finally succumbed to the traditional representation of woman. Ila is the classic case of modern woman's dilemma in hard core patriarchal society. Ila is a very interesting female character by Ghosh. She represents the modern women, their catch-22 situation, and their irrevocable depression. Liberation is still faraway glory for woman. 
"But I am free" (35) Ila proclaimed, but later in night club when Robi did not allow her to dance with two lusty businessmen she said to Narrator- "Do you see now why I've chosen to live in London? Do you see? It's only because I want to be free" (98). Was she really free in London? Her freedom in London was like a mirage, short lived and disappointing. She struggled hard to adjust in her world. Her relationships are quite indicative of her struggle and depression. She is very much sentient but the world forced her to be mechanical. She knows very well the infidelity of her husband, Nick Price, still she decided to be with him. Her first love interest Jamshed Tabrizi has rejected her. Her relationship with her second boyfriend is mechanical which reminds us of the relationship, the 'welcome of indifference,' that typist has with her boyfriend in T S Eliot's The Waste Land. likewise "she [Ila] spoke of her last lover's legs, the words had nothing to do with an excitement stored in her senses, but were just a string of words that she would remember while they sounded funny and then forget as completely as she had the lover and his legs" (33).

Tha'mma was right in her proclamation- "But that is not what it means to be free" (98). However, she said this line in a different context of nationalism, but still this is perfectly apt for Ila. Was she really free in London? Why even after being more resourceful than Nick Price, she is secondary to him? Why she happily succumbed to Nick's infidelity, humiliation and disrespect? Where has gone her spirit of freedom? The answer lies in the engraved performativity to which we all are subjected. Does not matter how much free we think of ourselves, we were all in chain, as Rousseau beautifully puts it 'Man is born free, and everywhere he is in chain.'

Ila represents the perfect case of gendering. Her eternal passion for beauty; her interest in house game, where she performed a lady of the house and asked Narrator to go out for work; her fascination for Nick Price, who is a European, stronger, taller, mightier and three years elder than her (thus in every sense capable of being her master); her chiding to Narrator for being afraid of dark underground room- "Coward, she said. Aren't you meant to be a boy?" (52), all are indicative of her performativity, and belief that beauty can give woman everything - good husband, popularity, attention, just everything.

Being a woman one can never give Hegelian 180 degree turn to someone who did not address you as a woman. Can a woman accept her subject-hood as something else, e.g. as a man? If we use 'he' for Ila or for any woman, can it be accepted. Language, culture, economy, knowledge, and science have already defined woman, which is always difficult to redefine. Ila from the beginning set herself perfectly in that mould of woman.

"For Ila the current was the real" (33). That is the trouble with modern women. They neither want to recognize their roots nor want to refine their ways for future. They act like warrior without purpose. All these women enjoy their life only for short span but as time passes, they got disillusioned. As patriarchy has never changed its basic tenets, but only modified their modus operandi. The so-called 'respect' is still reserved for those women who thoroughly submit to patriarchal set-up. They enjoy rebellious women but never accept them in their society. Such women just add adventure to their lives. This situation creates 'alienation,' 'separation,' 'dejection' and neurotic symptoms in women despite of being financially independent. Our own society has experienced the fall of many such successful women who have committed suicide due to their inability to cope with their predicament, e.g. Parveen Babi, Silk Smitha, Marilyn Monroe and many more.

Apparently, Ila has rejected the traditional notion of femininity, by being bold and modern, which is quite clear by her conduct and choice of words. Similarly, she defy the traditional Indian norms of clothes and hairstyle, she wears western clothes and cut her hair short. Still in the end she admits - "I never did any of those things: I'm about as chaste, in my own way, as any woman you'll ever meet" (207). To some extent, Ila was self deceptive. She lived her desired world through the surreal life of Magda.

Magda, Ila's doll is a simple case of 'transference' and 'displacement.' "Not Magda the doll, Ila cried. This is the real Magda" (78), for Ila Magda is real; it is the case of 'displacement.' Magda is her acted-out-fantasy. What Ila has failed to achieve in her real life she achieved them through the surreal life of Magda-love of Nick Price, paragon beauty, all attention, everything that she wishes. It is sort of 'wish-fulfillment.'

The little redacted episode of fight with Denise in school, where Nick Price saved her, clearly shows how Ila reinvented things from her real life to suit her desired emotions. She told Narrator that Nick fought with Denise for her sake but in reality Nick used to avoid her as he did not want to be seen with an Indian. It was quite painful for her to digest that the man she deeply love, completely loathes her. So she started living in her make-believe world 
like the heroine of Glass Menagerie by Tennessee William. Through her dream-world, she maintained her sanity who otherwise would sink to neurosis.

Power and superiority is naturally associated with masculinity, whereas beauty with femininity. To motivate someone we say 'be a man' nobody say 'be a woman.' Women who represent superior qualities, are generally associated with man. "Denise was very big, bigger than the bigger boy in the class. And she was very strong too: she had once knocked out a boy's teeth with a punch" (81). Here Denise represents strength, a masculine phenomenon, not a female. She became metaphorical man. What I mean to say is that if woman possesses strength or any other superior qualities, she does not qualify femininity but surprisingly only glorify masculinity. Thus under patriarchy femininity cannot be redeemed from her secondary status. For man it is always a win win situation: chit bhi mere, pat bhi mere, aur anda mere bap ka.

In another good example of gendering, Ghosh clearly shows how every aspect of life including house is a victim of set mould of performativity. The house-game that Ila used to play with Narrator shows how the social values left indelible imprint on children, and how they imitate these roles from their early childhood. Sex is always an effect of power, which is permeated through mind and body. The household means - a man, his wife, and children; man as bread-earner and woman as child-caring Aaya (governess). Man must go to office and woman take care of children. Ila said desperately "A house has to have a baby" (78), "You have to go to the work now" (79).

At the same time, households are deliberately made mysterious, for mystery is not subjected to rational analysis. Ila said to Narrator "you cannot play Houses out in the garden . . It has to be somewhat dark and secret . .." (76-77). For a long time social values, culture, religion, and household were made sacred by keeping it out of the reach of rationality and scientific discourse, which helped to maintain the subordination of women. We cannot interfere in people's house; it is their ghar ka mamla. Even in $21^{\text {st }}$ century, marital rapes cannot be punished under law.

Mayadebi as an epitome of beauty and Shri Himangshushekhar Datta Chaudhuri, the Shaheb as a white collared man are the best example of genderised concept of man and woman. Man symbolize authority and power whereas woman symbolize entertainment, a mere tantalizer.

One of the most groundbreaking contributions of Ghosh in the field of sexuality was gone unnoticed for many years. He is the one who gave us the proper term to combat Freud's 'penis envy.' We can even credit him for coining that revolutionary term "vagina-envy" (21). Though long ago psychoanalyst Karan Horney has retaliated Freud with her notion of 'womb envy,' which believes that it is men who are adversely affected by their inability to bear children. Whereas Ghosh used this term "vagina-envy" to show the advantage, that woman has just because she is not man, unlike 'penis envy,' which denotes that woman is lack and has disadvantages because they do not have phallus.

Ghosh explained how patriarchy has created two worlds - one for man and another for woman. Technically, except procreative function, there is hardly any major difference between male and female. There is vast possibility for common ground, which patriarchy deliberately tries to hide and projects things as such that we naturally believe in the existence of two worlds.

All the characters in the $S L$ bear the brunt of this two worlds. Narrators' relation with Ila and May are quite complicated. Ila ruined her life by her arrogant ignorance. She cast her pernicious shadow on Narrator. Narrator's love for Ila is purely sensual from the beginning, which is evident on many occasions. In his childhood, while playing house game he suddenly became aware of Ila's body, he wants to touch her and feel her with his tongue. This same passion continued to his adult life. This sensuality is equally balanced by profound love, which is evident from the tears, that Narrator often used to shed in utter helplessness of his unrequited love of Ila:

I knew she had taken my life hostage yet again; I knew that a part of my life as a human being had ceased: that I no longer existed, but as a chronicle. (123)

What is so interesting is that he wants to hide his sensual feelings for Ila "not for shame, but merely to preserve my friendship with her" (89). He preferred philia (friendship) over lust. In another scene when Ila left him alone to be with Nick, he felt the same aching pain and shed tears in helplessness, but he never forced himself on her. That makes him a true gentleman. 
SL also focused on the psychology of children. The Narrator is deeply infatuated by his cousin Ila. Basically, Ila was Narrator's 'fantasy,' which exert its pleasure by being unfulfilled. In the same way, Nick Price was Ila's 'fantacy.' Ila is exotic for Narrator; her clothes, year book all matter for him. He immediately disapproved her looks when she came in Bengali sari. She is his 'object petit $a$ '. She gives him constant sense that something is missing in his life. She is his 'desire' in Lacanian sense, i.e., the desire for something that is missing and constant search for the missing object.

She [Narrator's mother] had made public then and forever, the inequality of our needs; she had given Ila the knowledge of her power and she had left me defenseless; naked, in the face of that unthinkable, adult truth: that need is not transitive, that one may need without oneself being needed. (48)

Similarly, love is not transitive; one may love without oneself being loved. Ghosh here tried to establish that it is basically "the inequality of our needs" not gender that decide our place in love. The Narrator even being a man is in disadvantage to Ila, who is an authority here, as to accept him or reject him, thus powerful. Ila is Narrator's desire/need, Narrator is not Ila's desire/need. Narrator was deeply in love with Ila from his childhood. He was always uncomfortable with her love interests. He filled with deep jealousy when he first came to know about Nick:

After that day Nick Price, whom I had never seen, and would, as far as I knew, never see, became a spectral presence beside me in my looking glass; growing with me, but always bigger and better, and in some way more desirable - I did not know what, except that it was so in Ila's eyes and therefore true. (55)

Latter when he met Nick Price after seventeen years, he realized that Nick was not as big as Ila has projected him. This is how discourse works, and establish false as true. On the same pattern, Narrator believed whatever Tridib told him yet everything was not true. But for Narrator all was true. Later Narrator identify with Nick Price_- "I had found at last the kindred spirit whom I had never been able to discover among my friend" (58). Psychologically he convinced himself of his victory in the sense that at last Ila choose his kind if not him. In the same way, May Price relates Narrator to Tridib as he is Tridib's true disciple, to get out of her 'mourning.'

Narrator represents 'will to know' in Foucaultdian sense. Narrator likes Tridib so much, for he is the one who quench his thirst for knowledge. Tridib gave him his world- "I could not forget because Tridib had given me worlds to travel in and he had given me eyes to see them with" (22). He saw London through his eyes; he saw the whole world through his eyes. He is inquisitor, a quester and Tridib is his spring of knowledge.

Narrator works as Tridib's foil or shadow. They are two existence rooted in one identity. Narrator's relation with Tha'mma, his grandmother is equally interesting. It is quite similar to Paul Maurel's relation with his mother Gertrude Maurel in D. H. Lawrence's novel Sons and Lover. Both women-Ila and Tha'mma — act like 'boa constructor,' the perfect term that G B Shaw used for women's deleterious influence on man in Man and Superman.

Tha'mma wants Narrator to become something that fit her definition. She does not like his love for Tridib and Ila. And surely going to object May, if she would have known about his love for her. Like Gertrude she opposes all those who are her strong contender in casting their power on him, which resemble lover-like jealousy. Precisely this tussle of power and jealousy resemble 'Oedipus complex': "my heart fills with love for her-love and that other thing, which is not pity but something else." Narrator himself admits "she had always been passionate a person to find a real place in my late-bourgeois world" (100-02). He can feel her grip over his soul even after her death: "her resurrected hand, reaching out to me after her death, as it had all through my childhood" (102). Tha'mma has an easy access to Narrator, she knew him more than he know himself: "I have never understood how she learnt of the women I had visited a couple of times, with my friends; nor do I know how she saw that I was in love with Ila so long before I dared to admit it to myself' (103). As a true lover, she just wants to redeem him from the ominous shadow of Ila, as she knew very well that Ila is never going to accept him in her life.

Tha'mma has always felt a lover like jealousy and sautan's (other woman) hate for Ila. She said satirically to Narrator's mother that she should not prepare a dinner for him as Ila is in Calcutta: "You'd better forget about his dinner. You're not likely to see him this evening. . . . Because . . . her eyes boring into mine; Ila is here. . . .with her hair cut short, like the bristle on the toothbrush, wearing tight trousers like a Free School Street whore" (88). She used to call her "whore", "memshaheb whore" (99), "English whore" (99). She held Ila responsible for Narrator's deteriorating morality: "Why have you let that whore trap you? She whispered. I know it's she who's sent you into 
the arms of those whores you go to in Delhi. Do you think I don't know? Did you think I would allow it?" (100). Here she acts as 'superego.' Even on her deathbed being very weak she ordered, "Did you think I would allow it?"

She never liked Ila, never had any sympathy for her (Ila) desire to be free, despite of being a woman who has great regard for self-respect, independence and freedom. She simply hates her because somewhere Narrator deeply loves her. "It's not freedom she wants, said my grandmother ... She wants to be left alone to do what she pleases: that's all that any whore would want. She'll find it easily enough over there; that's what those places have to offer. But that is not what it means to be free" (98). Here Tha'mma represents hackneyed mindset which takes sexual freedom negatively particularly for woman. Any woman who wants to be free in her sexual matters immediately tagged as immoral, prostitute, low birth, a whore. Narrator also felt lover like privilege over Tha'mma's love: "I was very jealous, I remember. I had always taken it for granted that it was my own special right to love her; I did not know how to cope with the discovery that my right had been infringed by a whole school" (128).

Tha'mma represents 'superego' whereas Tridib represents pure 'id'. That is why Tha'mma was in direct confrontation with Tridib. Tridib was a rebel, that is what an 'id' stands for. 'Id' incorporates within itself a rebellious power that always disobeys 'superego' the established structure of power. He refused to be a successful person in worldly terms; he refused to hide his lust for May; he refused to be rational and fritter away his time in contradictory idleness. He wrote a pornographic letter to May Price. It is basically a case of 'fantasy' - an imagined scene in which the subject is a protagonist, and always represents the fulfillment of a wish. It is the case of "wishfulfillment.' "A section of a wall" that "had been knocked out, leaving a jagged, triangular breach" (153) which was dark obviously represents the hidden parts of Tridib's unconscious, that is the storehouse of our libidinal sentiments - the 'id.' Here in this case the 'id' was registered in the letter without what D. H. Lawrence calls 'the fribbling intervention of mind, or moral.' At the same time Tridib truly loves May Price, "you're my love, my own, true love, my love-across-the-sea" (193), which proves the claim of many that spiritual and physical love are basically two facets of one coin, and cannot be detached from each other.

The triangle between Tridib, Narrator and May reminds us the Tristan and Iseult love story. Isolde was the wife of King Mark of Cornwall. She was brought from Ireland by the king's nephew Tristan. She and Tristan accidentally drank the aphrodisiac given to her by her mother for her marriage, were separated as lovers, and finally died together. However, in May and Narrator's case they are redeemed from their sufferings by their aphrodisiac encounter.

Tridib is the mysterious man. He is the one who discarded the theory of clash between 'id' and 'morality.' He proved that 'superego' is not conditional in every case. His pornographic letter to May is nothing but the celebration of 'id' without any intervention of 'superego.' His personality hardly shows any conflict on the base of 'id.' His feelings for May are purely physical and unbridled without any fribbling intervention of mind and rationality. Yet he did not show even a single sign of perversity. His case proves the credibility of Lawrence's theory of 'religion of blood,' who emphatically professed that there is nothing embarrassing about sex. Tridib proves that having ardent passion does not disqualifies someone as good human being.

He said to me (Narrator) once that one could never know anything except through desire, real desire, which was not the same thing as greed or lust; a pure, painful and primitive desire, a longing for everything that was not in oneself, a torment of the flesh, that carried one beyond the limits of one's mind to other times and other places, and even, if one was lucky, to a place where there was no border between oneself and one's image in the mirror. (32)

In these lines, Ghosh gave us a very important lesson of psychoanalysis. First he discarded Freud's claim that dreams are the store of repressed libidinal wishes. Secondly he accepted that dreams can be used as a mechanism to sustain in life. For we cannot achieve all things in our real life. In this situation, dreams can save us from utter dejection because in dreams wishes are not just seem to be fulfilled but really fulfilled. As the satisfaction, that we have in dreams is equal to the real satisfaction that one can get from real stuff. He also confirms D. H. Lawrence claim of primitive desire. Thirdly, he proposes the solution of disintegration of 'ego' in Lacan's 'mirror stage', which child confront after realizing that the image in the mirror is not of his self but its reflection-"there was no border between oneself and one's image in the mirror."

$S L$ also presents the dilemma of modern man/woman who live in constant realization of 'objet petit $a$ ' - the constant sense that something is missing in our life. Most of the characters in $S L$ represent Lacanian form of 'lack' - the need 
for something that does not belong to their world. They ran after 'desires' which unlike 'need' cannot be satisfied, resulted in unceasing jouissance - pleasure in pain, followed by non rapport.

\section{Tridib + reality $=$ non rapport \\ Narrator + Ila $=$ non rapport \\ Ila + Nick Price $=$ non rapport}

$S L$ also depicts body as a playground of power: "You can't build a strong country . . . without building a strong body" (9). If one gives a close look to life in general, we shall realize that we are not the true owner of our bodies. ' $\mathrm{I}$ ' is never been the first person, nor it can be. As Lacan distinguished 'subject' from 'I.' Power has its own claim on our bodies. All bodies across culture and nation are genderised to suit the needs of power. It executes on day today bases, percolating from top to bottom. Power has a pyramid structure. Even in democracy, power finally shrinks in few people-legislature, cabinet, and ministers. May be for five years, but they take decision for other. Even in democracy, it is not easy to challenge power or to change their decision. Raja Neel Rattan Holder, a character from 'Ibis trilogy' expresses this truth beautifully: "How was it possible that a small number of men, in the span of a few hours or minutes, could decide the fate of millions of people yet unborn?" (Ghosh, FOF 388). Sexuality is also victim of power. We really do not know what really 'sexuality' is. If technically it is same, then why there are innumerable sexual experiences in the world. In true sense it is the "das ding" (the thing), a core of 'the real' that is missing from the symbolic.

Ghosh's priceless contribution to feminism is that he tried to deconstruct the characteristics of femininity. All his heroines transgress the set definition of femininity. They are not soft, curvaceous and delicate; still attract their lovers acutely. He tried to break that sexist mentality which prevails in society. Delineating May Price, he said:

She was not sexy, not in the ordinary way_-she was thickset with broad shoulders, and not very tall. She wasn't beautiful or even pretty in the usual sense for she had a strong face and a square jaw, but she had thick straight hair which came down to the shoulder in a glossy black screen, like a head-dress in an Egyptian frieze, and she had a wonderful, warm smile which lit up her blue eyes and gave her a quality all her own, set her apart. (Ghosh, SL 1213)

May Price suffered 'alienation' and 'separation'; she was also a victim of 'death drive' after the death of Tridib, which is always self-destructive, rather than other-destructive. She left her house, and start living in small room, with meager furnishings. Her use of the word 'empty' is indicative of her 'alienation' and 'separation.' She also presents the case of 'guilt.' She continuously suffers from the 'guilt' for Tridib's death. Consequently, she withdrew herself from world and tried to find her peace in working for Amnesty and Oxam and other relief agencies. She herself admitted to Narrator that she works with orchestra only to maintain her living otherwise she has lost her interest in music too.

After Tridib's death, May Price plunged into the state of 'mourning' — a period of serious depression and distressfor a long time until Narrator enters in her life. However, she did not mean to kill Tridib. At that time, she did not realize what consequences would result from her idealism. Still she has some role in Tridib's death. This is what Foucault calls, 'the disjunction of intention and its actual effects' - where particular consequence is inevitable effect of an act, but cannot be seen as planned aim. Later she recognizes her loss and move forward for her healing, a marked feature of 'mourning.'

Do you think I killed him? . . . I used to think so, she said. I thought I'd killed him. I used to think: perhaps he wouldn't have got out of that car if I hadn't made him, if I'd understood what I was doing. . . .For years I was arrogant enough to think I owed him his life. But I know now I didn't kill him; I couldn't have, if I'd wanted. He gave himself up; it was a sacrifice. I know I can't understand it, I know I must not try, for any real sacrifice is a mystery. (277)

Thus, finally she overcome her 'guilt' and moved forward. She accepted Narrator as Tridib's standby. It is a case of the second level 'transference,' where unconscious wishes and impulse show up in a social situation, or onto the analyst. Freud calls it 'new editions or facsimiles' in which old impulse and fantasies are transferred to the doctor. Of course, the doctor is not the literal doctor but can be anyone who wants to heal you. In May's case, it is Narrator. May wants to preserve Tridib's memory, at the same time she wants to annul it. She overcome it by claiming, "I 
didn't kill him," but simultaneously preserves it in the form of Narrator, as Narrator is the extension of Tridib's existence. It is the perfect case of aufhebung.

\section{Works Cited:-}

1. Banerjee, Joydeep. The Novels of Amitav Ghosh: A Critical Study. New Delhi: Sunrise Publications, 2009. Print.

2. Ghosh, Amitav. The Shadow Lines. New Delhi: Ravi Dayal Publisher, 1988. Print.

3. ---. Flood of Fire. New Delhi: Hamish Hamilton, 2015. Print.

4. Hill, Philip. Lacan for Beginners. Chennai: Orient BlackSwan, 2011. Print.

5. WWW.Google.co.in. Web. 25 March 2016. <https://en.wikipedia.org/wiki/Modern_girl>. 